\title{
LOWER ESOPHAGEAL SPHINCTER PRESSURE MEASUREMENT UNDER STANDARDIZED INSPIRATORY MANEUVEURS
}

\author{
Medidas das pressões do esfíncter esofágico inferior por manobras inspiratórias padronizadas
}

Jeany Borges e Silva RIBEIRO, Esther Cristina Arruda Oliveira DIÓGENES, Patrícia Carvalho BEZERRA, Tanila Aguiar Andrade COUTINHO, Cícera Geórgia Félix de ALMEIDA, Miguel Ângelo Nobre e SOUZA

From the Laboratório de Gastroenterologia, Universidade Federal do Ceará (Gastroenterology Laboratory, Ceará Federal University), Fortaleza, CE, Brazil.

HEADINGS - Threshold maneuver. Esophagogastric junction pressure. Crural diaphragm. Gastroesophageal reflux. Lower esophageal sphincter.
ABSTRACT - Background: Through rhythmic variations, the diaphragm influence lower esophageal sphincter (LES) pressure acting as an external sphincter. LES pressure recording is characterized by increased pressure in inspiration due to contraction of the diaphragmatic crura that involves the sphincter. Aim: To describe a method of measuring LES pressure during standardized inspiratory maneuvers with increasing loads. Methods: The study population comprised of eight healthy female volunteers (average age of 31.5 years). An esophageal high-resolution manometry and impedance system was used for measuring the LES pressure during 3-second inspiratory efforts under 12,24 and $48 \mathrm{~cm} \mathrm{H}_{2} \mathrm{O}$ loads (Threshold maneuvers). Results: There was a significant difference between the average maximum LES pressure and the average maximum basal LES pressure during the first $(76.19 \pm 17.92$ difference, $p=0.0008)$, second $(86.92 \pm 19.01$ difference, $p=0.0004)$, and third seconds of the maneuver $(90.86 \pm 17.93$ difference, $\mathrm{p}=0.0002$ ), with 12,24 and $48 \mathrm{cmH}_{2} \mathrm{O}$ loads. Conclusion: This maneuver is a standardization of the inspiratory LES pressure and may better differentiate patients with reflux disease from healthy individuals, and may also be useful for monitoring the treatment of these patients through inspiratory muscle training.

\section{Correspondence:}

Miguel Ângelo Nobre e Souza

Email:mans@ufc.br

Financial source: none

Conflicts of interest: none

Received for publication: 19/02/2015

Accepted for publication: 05/05/2015

DESCRTORES: Manobra Threshold. Pressão da junção esofagogástrica. Crura diafragmática. Refluxo gastroesofágico. Esfíncter esofágico inferior.
RESUMO - Racional: Através de variações rítmicas, o diafragma influencia a pressão do EEI, atuando como um esfíncter externo. O registro manométrico da sua pressão caracterizase por aumento de pressão na inspiração resultante da contração da crura diafragmática que envolve o esfíncter. Objetivo: Descrever um método de medida da pressão do esfíncter esofágico inferior (EEI) durante manobras inspiratórias padronizadas, com cargas crescentes. Métodos: Oito voluntários sadios (sexo feminino, média de idade de 31,5 anos) participaram do estudo. Uma manometria esofágica de alta resolução e impedanciometria mediram a pressão do EEI durante manobras inspiratórias com o Threshold sob cargas de 12, 24 e $48 \mathrm{~cm} \mathrm{H}_{2} \mathrm{O}$. Resultados: Comparando-se as médias houve diferença significativa entre a pressão máxima do EEI e a sua pressão basal máxima durante o primeiro (diferença de 76,19 $\pm 17,92, p=0,0008$ ), segundo (diferença $86,92 \pm 19,01, p=0,0004$ ) e terceiro segundos da manobra (diferença $90,86 \pm 17,93, p=0,0002$ ), tanto com carga de $12 \mathrm{~cm}$ de $\mathrm{H}_{2} \mathrm{O}$, quanto com 24 e $48 \mathrm{~cm}$. Conclusão: Esta manobra é uma padronização da pressão inspiratória do EEI e pode diferenciar melhor pacientes com doença do refluxo de indivíduos sadios, podendo também ser útil na monitorização do tratamento desses pacientes por meio do treinamento muscular inspiratório.

$T$ he lower esophageal sphincter is a 2-4 cm high pressure zone with intraabdominal and intra-thoracic segments. The pressure inversion point separates the lower esophageal sphincter (LES) segments and the intra-thoracic yields a negative pressure during inhalation. This segment is approximately $0.5 \mathrm{~cm}$ long, generally located in the middle of the high pressure zone, and related to the crural diaphragm. The LES normally extends two to four centimeters distal to the inversion point and corresponds to the intra-abdominal segment. The high pressure zone is asymmetrical with the left lateral and posterior pressures significantly higher ${ }^{7}$.

The diaphragm influences rhythmically the LES pressure, acting as an external sphincter. Its manometric profile is represented by an increase in pressure during inhalation, due to the contraction of the diaphragm that skirts the esophagus ${ }^{7}$.

There is evidence that the inspiratory pressure better distinguishes reflux esophagitis patients from controls ${ }^{8}$. Some patients with esophagitis may not increase inspiratory LES pressure during inhalation as much as controls ${ }^{8}$ and some adaption may occur in other conditions ${ }^{9}$. The diaphragm contraction squeezes and lowers the gastroesophageal junction during inspiration.

The topographic profiles of the gastroesophageal juntion delivered by high 
resolution manometry (HRM) shows both its pressure and lowering.

The aims of this study was to describe a measurement method of the LES pressure during standardized inspiratory maneuvers with stepwise increasing efforts.

\section{METHODS}

\section{Volunteers}

Eight healthy volunteers (without GERD symptoms) were submitted to HRM of the esophagus in the Gastroenterology Research Laboratory of the Clinical Medicine Department of the Ceará Federal University (Fortaleza, CE, Brazil). The study was a qualitative and quantitative in humans. The ethical principles concerning human research set by the 196/96 resolution of National Health Council was followed.

\section{Manometry}

HRM is a standard method of measuring the pressure gradient across the gastroesophageal junction and its relaxation, allowing accurate diagnosis of diseases associated with hyper or hypotonicity. It also allows the localization of the LES upper border which is necessary for $\mathrm{pH}$ monitoring probe positioning ${ }^{4}$.

HRM was performed with volunteers in the supine position and after at least $6 \mathrm{~h}$ fasting. The probe had 36 pressure $1 \mathrm{~cm}$ apart and 18 impedance sensors $2 \mathrm{~cm}$ apart (Given Imaging, Yokneam, Israel). Pressure calibration was performed at 0 and 300 $\mathrm{mmHg}$ and zeroed to atmospheric pressure before the procedure. The probe was positioned through one nostril with at least five sensors distal to the diaphragm. The protocol included a basal period, six 5-ml saline swallows and a respiratory maneuver ${ }^{2}$.

\section{Inspiratory maneuver}

The respiratory maneuver has been previously descried ${ }^{2}$. The volunteers stayed at the supine position without swallowing and the LES pressure was measured for 20 seconds before and during the maneuver. The maneuver consisted of fast and forced inhalation through a membrane valve (Threshold IMT, Philips Respironics, Andover, MA, USA) whose closing pressure $\left(\mathrm{cmH}_{2} \mathrm{O}\right)$ could be adjusted by a compression spring (Figure 1$)^{1}$ All volunteers trained the maneuvers and undertook inhalations with 12,24 , and $48 \mathrm{cmH}_{2} \mathrm{O}$.

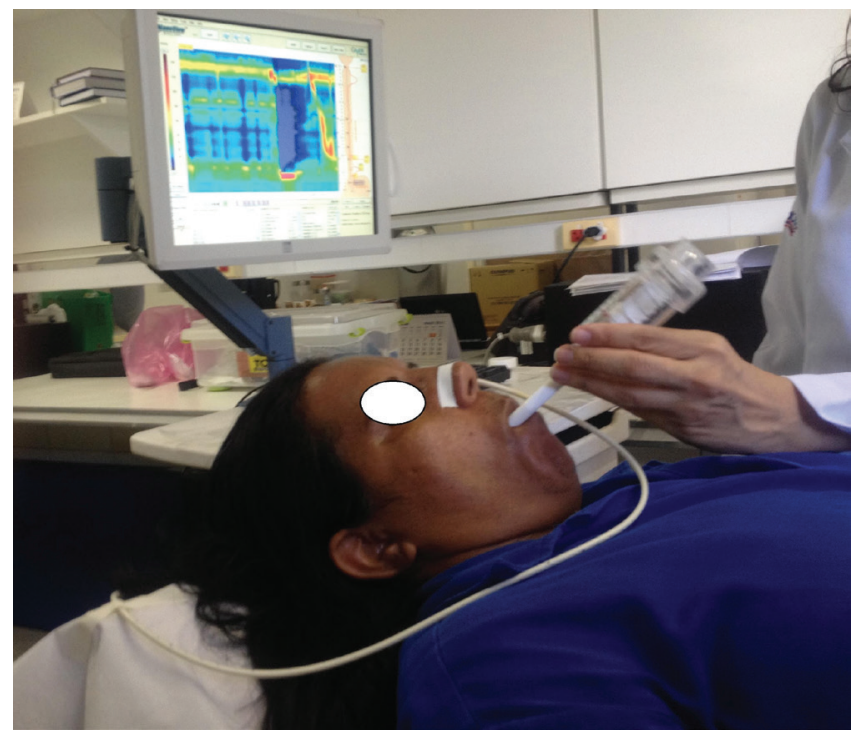

FIGURE 1 - Volunteer performing an inspiratory maneuver with the Threshold device

Data analysis

Variable definition (Figure 2)

The following variables were measure with the ManoView
Analysis Software 3.0, with $20 \mathrm{mmHg}$ isobaric pressure.

The average basal pressure $(\mathrm{mmHg})$ was the mean pressure of the " $\mathrm{A}$ " rectangle with the height defined by the proximal and distal borders of the LES and the length equal to six seconds.

The basal contractility integral (IC) was the product pressure $x$ height $x$ length of the " $\mathrm{A}$ " rectangle inside the $20 \mathrm{mmHg}$ isobaric contour.

The minimal inspiratory oral pressure $(\mathrm{mmHg})$ was the lowest hypopharyngeal pressure during the maneuver.

The minimal inspiratory esophageal pressure $(\mathrm{mmHg})$ was the lowest esophageal pressure during the maneuver.

The LES lowering was figured out on the " $B$ " rectangle, defined by two angles, first, the right angle formed by the horizontal line passing through the upper border of the LES and the vertical line at the start of the maneuver. The second angle was formed by a vertical line at a " $\mathrm{t}$ " time and the LES distal border at time t. The LES lowering (ds) was the height of the rectangle $B(\mathrm{~cm})$.

The maximal LES pressure $(\mathrm{mmHg})$ was the highest pressure in rectangle $B$ at each time $t$.

The LES contractility integral $(\mathrm{CI})$ was the product pressure $x$ height $x$ length of the " $B$ " rectangle inside the $20 \mathrm{mmHg}$ isobaric contour at each time t.

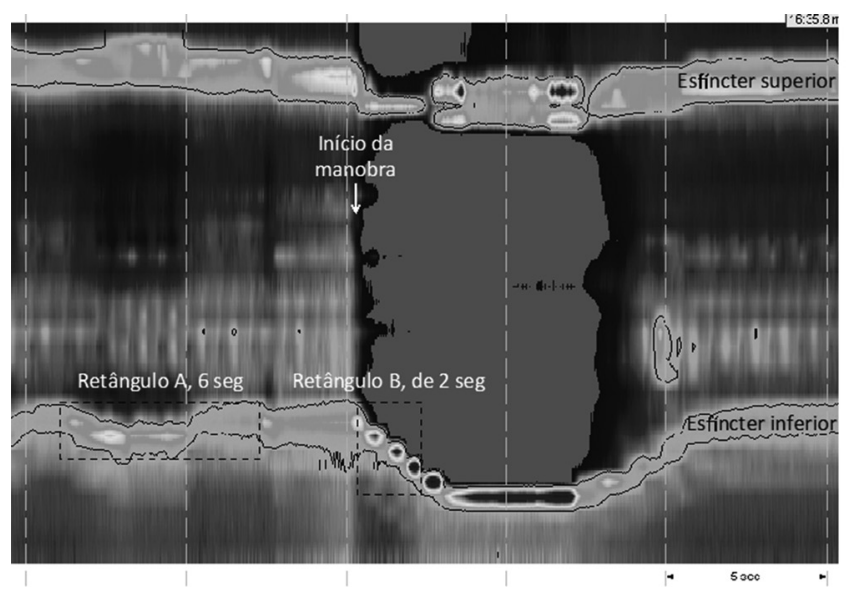

FIGURE 2 - Variables obtained during the Threshold maneuver

Time assumed value of tequal to 1,2, and 3 seconds. Groups of similar variables were tested for distribution with the Student t test at a significance cutoff of 0.05 .

\section{RESULTS}

Eight female healthy volunteers aged 31.5 years in average (21-47 years) and average BMI of $24.28 \mathrm{~kg} / \mathrm{m}^{2}(17.3-30.61 \mathrm{~kg} /$ $\mathrm{m}^{2}$ ) were studied.

The LES average basal pressure before the maneuver with $12 \mathrm{cmH}_{2} \mathrm{O}$ load was $61.61 \pm 17.63$. The basal CI was 198.91 \pm 117.92 (Table 1).

During the $12 \mathrm{cmH}_{2} \mathrm{O}$ maneuver, there was a stepwise lowering of the diaphragm (DS) across the first, second, and third seconds $(5.3 \pm 0.78 \mathrm{~cm}, 5.9 \pm 0.89 \mathrm{~cm}$, and $6.06 \pm 0.98 \mathrm{~cm}$, respectively). The DS rate decreased across the maneuver $(5.48 \pm 0.77 \mathrm{~cm} / \mathrm{s}$ at $1 \mathrm{~s}, 2.95 \pm 0.46 \mathrm{~cm} / \mathrm{s}$ at $2 \mathrm{~s}$, and $2.01 \pm 0.33$ $\mathrm{cm} / \mathrm{s}$ at $3 \mathrm{~s})$. On the other hand, the maximal pressures and the $\mathrm{CI}$ increased across the maneuver (Table 1). The LES maximal pressures increment were higher across this maneuver (1s: $76.19 \pm 17.92, p=0.0008 ; 2 \mathrm{~s}: 86.92 \pm 19.01, p=0.0004 ; 3 \mathrm{~s}: 90.86 \pm 17.93$, $p=0.0002)$. Similar results were obtained for 24 and $48 \mathrm{cmH}_{2} \mathrm{O}$ (Tables 2 and 3), except for the third second of $24 \mathrm{cmH}_{2} \mathrm{O}$ load. 
TABLE 1 - LES variables before and during the maneuver with $12 \mathrm{cmH}_{2} \mathrm{O}$ load

\begin{tabular}{|c|c|c|c|}
\hline & Parameters & Mean $\pm S D$ & Variation \\
\hline \multirow{5}{*}{ Basal } & Maximal LES pressure & $61.61 \pm 17.63$ & $38.4-93.5$ \\
\hline & Basal LES CI & $198.91 \pm 117.92$ & $70.6-428.2$ \\
\hline & Minimal oral pressure & $-16.15 \pm 8.38$ & $-36.2-(-11.8)$ \\
\hline & Minimal esophageal pressure & $-41.92 \pm 18.74$ & $-86.9-(-28.6)$ \\
\hline & Average intragastric pressure & $16.22 \pm 4.06$ & $11.4-24.4$ \\
\hline \multicolumn{4}{|c|}{ Maneuver time } \\
\hline \multirow{4}{*}{1 second } & DS & $5.3 \pm 0.78$ & $4.4-6.4$ \\
\hline & DS/DT & $5.48 \pm 0.77$ & $4.6-6.5$ \\
\hline & Maximal LES pressure & $137.8 \pm 47.51$ & $79.7-225.5^{\star}$ \\
\hline & LES CI & $101.87 \pm 46.67$ & $32-147$ \\
\hline \multirow{4}{*}{2 seconds } & DS & $5.9 \pm 0.89$ & $4.9-7.6$ \\
\hline & DS/DT & $2.95 \pm 0.46$ & $2.4-3.8$ \\
\hline & Maximal LES pressure & $148.53 \pm 50.81$ & $80.5-241.2^{\#}$ \\
\hline & LES CI & $220.78 \pm 114.64$ & $68.6-418.8$ \\
\hline \multirow{4}{*}{3 seconds } & DS & $6.06 \pm 0.98$ & $4.9-8$ \\
\hline & DS/DT & $2.01 \pm 0.33$ & $1.6-2.7$ \\
\hline & Maximal LES pressure & $152.47 \pm 47.56$ & $92.2-241.2^{2}$ \\
\hline & LES CI & $328.18 \pm 167.1$ & $133-627.1$ \\
\hline
\end{tabular}

TABLE 2 - LES variables before and during the maneuver with $24 \mathrm{cmH}_{2} \mathrm{O}$ load

\begin{tabular}{|c|c|c|c|}
\hline & Parameters & Mean \pm SD & Variation \\
\hline \multirow{5}{*}{ Basal } & Maximal LES pressure & $64,32 \pm 14,29$ & $49-93,5$ \\
\hline & Basal LES CI & $252,81 \pm 150,04$ & $105,5-489,6$ \\
\hline & Minimal oral pressure & $-23,57 \pm 8,21$ & $-43,2-(-17,1)$ \\
\hline & Minimal esophageal pressure & $-48,8 \pm 32,14$ & $-128-(-33,9)$ \\
\hline & Average intragastric pressure & $17,5 \pm 5,87$ & $10,5-27$ \\
\hline \multicolumn{4}{|c|}{ Maneuver time } \\
\hline \multirow{4}{*}{1 second } & DS & $4,77 \pm 0,85$ & $3,9-6,3$ \\
\hline & DS/DT & $4,8 \pm 0,84$ & $3,9-6,3$ \\
\hline & Maximal LES pressure & $134,42 \pm 32,18$ & $88-168^{*}$ \\
\hline & LES CI & $105,5 \pm 38,63$ & $46,7-149,5$ \\
\hline \multirow{4}{*}{2 seconds } & DS & $5,62 \pm 0,93$ & $4,6-7,2$ \\
\hline & DS/DT & $2,75 \pm 0,47$ & $2,3-3,6$ \\
\hline & Maximal LES pressure & $152,34 \pm 35,09$ & $101,1-207,3^{\#}$ \\
\hline & LES CI & $217,11 \pm 75,4$ & $103-317,9$ \\
\hline \multirow{4}{*}{3 seconds } & DS & $5,74 \pm 1,09$ & $4,6-7,8$ \\
\hline & DS/DT & $1,9 \pm 0,37$ & $1,56-2,6$ \\
\hline & Maximal LES pressure & $125,06 \pm 69,14$ & $-29,6-188,9^{2}$ \\
\hline & LES CI & $333,91 \pm 124,6$ & $175,8-500,3$ \\
\hline
\end{tabular}

LES=lower esophageal sphincter; $\mathrm{CI}=$ contractility integral; $\mathrm{DS}=$ diaphragm lowering $\mathrm{DS} / \mathrm{DT}=\mathrm{DS}$ rate; $\mathrm{SD}=$ standard deviation. ${ }^{*} \mathrm{p}=0.0001 ;{ }^{*} p<0.0001$, ${ }^{*} p=0.029$, versus maximal LES pressure (Student $t$ test).

TABLE 3 - LES variables before and during the maneuver with $48 \mathrm{cmH}_{2} \mathrm{O}$ load

\begin{tabular}{|c|c|c|c|}
\hline & Parameters & Mean \pm SD & Variation \\
\hline \multirow{5}{*}{ Basal } & Maximal LES pressure & $56,56 \pm 17,93$ & $26,6-86,7$ \\
\hline & Basal LES CI & $184,36 \pm 136$ & $-87-321$ \\
\hline & Minimal oral pressure & $-39,5 \pm 36,89$ & $-51,3-(-31,5)$ \\
\hline & Minimal esophageal pressure & $-55,77 \pm 29,77$ & $-128,8-(-37,7)$ \\
\hline & Average intragastric pressure & $17,45 \pm 6,32$ & $10-30,2$ \\
\hline \multicolumn{4}{|c|}{ Maneuver time } \\
\hline \multirow{4}{*}{1 second } & DS & $4,3 \pm 1,25$ & $2,7-6,2$ \\
\hline & DS/DT & $4,43 \pm 1,31$ & $2,7-6,5$ \\
\hline & Maximal LES pressure & $136,79 \pm 33,97$ & $94,9-190,9 *$ \\
\hline & LES CI & $104,3 \pm 49,8$ & $44-175,5$ \\
\hline \multirow{4}{*}{2 seconds } & DS & $4,8 \pm 1,43$ & $2,6-7,3$ \\
\hline & DS/DT & $2,4 \pm 0,71$ & $1,3-3,6$ \\
\hline & Maximal LES pressure & $140,95 \pm 33,95$ & $94,9-192,5^{\#}$ \\
\hline & LES CI & $206,63 \pm 79,35$ & $118,4-326,1$ \\
\hline \multirow{4}{*}{3 seconds } & DS & $5,28 \pm 1,33$ & $3,3-7,6$ \\
\hline & DS/DT & $1,75 \pm 0,44$ & $1,1-2,5$ \\
\hline & Maximal LES pressure & $150,76 \pm 40,41$ & $94,9-208,7^{\&}$ \\
\hline & LES CI & $312,19 \pm 105,47$ & $188,7-487,1$ \\
\hline
\end{tabular}

LES=lower esophageal sphincter; $\mathrm{CI}=$ contractility integral; $\mathrm{DS}=$ diaphragm lowering DS/DT =DS rate; $S D=$ standard deviation. ${ }^{*} p<0.0001 ;{ }^{*} p<0.0001$, ${ }^{\&} p<0.001$, versus maximal LES pressure (Student $t$ test).
Figure 3 shows the increase in LES pressure across the three loads of the maneuvers.

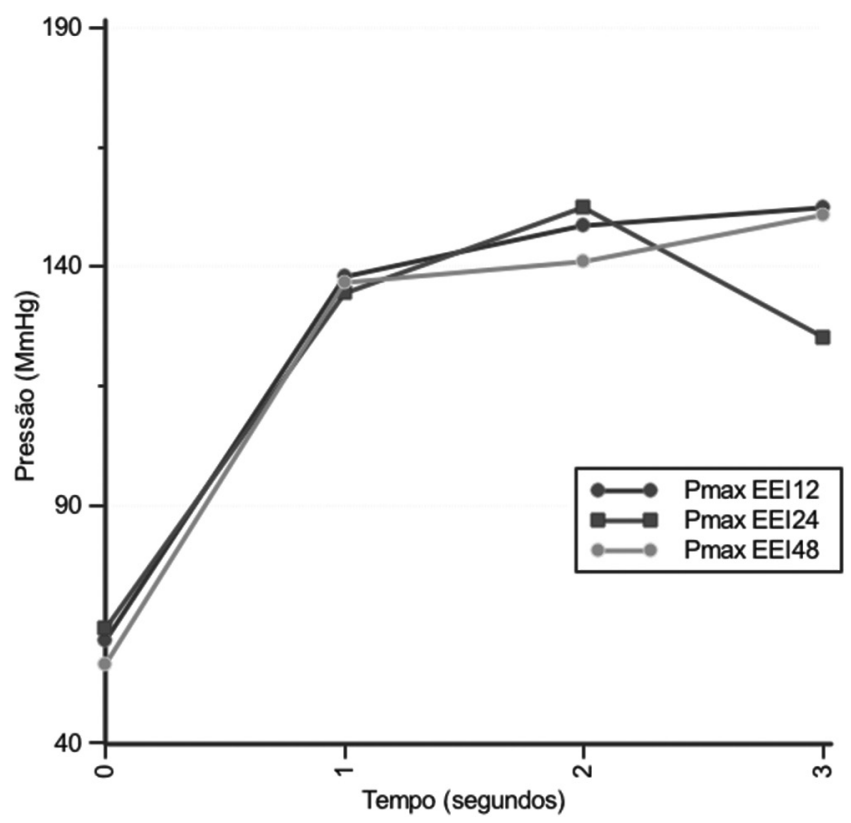

Pmax EEI 12 = Maximal LES pressure before and during Threshold maneuver with $12 \mathrm{~cm} \mathrm{H} \mathrm{H}_{2} \mathrm{O}$ load; Pmax EEI 24 = Maximal LES pressure before and during Threshold maneuver with $24 \mathrm{~cm} \mathrm{H}_{2} \mathrm{O}$ load; Pmax EEI 48 = Maximal LES pressure before and during Threshold maneuver with $48 \mathrm{~cm} \mathrm{H}_{2} \mathrm{O}$ load.

FIGURE 3 - LES pressure before and during the inspiratory maneuvers with loads of $12 \mathrm{cmH}_{2} \mathrm{O}, 24 \mathrm{cmH}_{2} \mathrm{O}$, and $48 \mathrm{cmH}_{2} \mathrm{O}$ at 1,2 , and 3 seconds

\section{DISCUSSION}

HRM allows real time analysis of the LES pressure and the components of the anti-barrier reflux. Then, it is an important tool for the pathophysiology study of GERD ${ }^{6}$.

The crural diaphragm contractions are also related to shifts in gastroesophageal junction pressure. Generally, these contractions are associated with respiration. There is a 10 to $20 \mathrm{mmHg}$ increase in pressure during normal inhalation, and 50 to $150 \mathrm{mmHg}$ during deep inspiration ${ }^{5}$. The Threshold device is used to strengthen the inspiratory muscles. It is made by one-way diaphragm valve kept in place by a spring which compression can be adjusted manually. Therefore, the inspiratory effort necessary to displace the membrane and allow airflow can be increased linearly. Inspiratory muscles are trained this way ${ }^{3,10}$. There is no effort during exhalation.

This inspiratory maneuver has been adapted to HRM in order to measure the gastroesophageal junction inspiratory pressure in GERD ${ }^{8,9}$.

During the $12 \mathrm{cmH}_{2} \mathrm{O}$ maneuver, there was a stepwise increase in the maximal inspiratory LES pressure, relative to the maximal basal pressure -2.23 times at the first second, 2.41 times at the second second, and 2.47 times at the third second. These relative increments were 2.09 times at the first second, 2.3 times at the second second, and 1.94 times at the third second for the $24 \mathrm{cmH}_{2} \mathrm{O}$ maneuver, and 2.41 times at the first second, 2.49 times at the second second, and 2.66 times at the third second for the $48 \mathrm{cmH}_{2} \mathrm{O}$ maneuver (Table 3).

The inspiratory maneuver depends on volunteer effort and collaboration. This is a weakness of this method as can be seen by the large variation of the maximal inspiratory LES pressure values. The relatively lower increase in the maximal pressure during the third second of the $24 \mathrm{cmH}_{2} \mathrm{O}$ maneuver could have occurred because of this drawback. On the other hand, the stepwise increase in LES pressure 
across the 1, 2, and 3 seconds of maneuver is a strong-point of the method. This attribute may help differentiate distinct pathological conditions.

\section{CONCLUSION}

This maneuver is a standardization of the LES inspiratory pressure measurement. It may better differentiate GERD patients from healthy individuals, since the former ones may have a crural deficiency and a lower inspiratory LES pressure. Furthermore, this maneuver may help monitor the efficiency of inspiratory muscle training for GERD ${ }^{8}$.

\section{REFERENCES}

1. Azeredo CAC. Técnicas para desmame do ventilador mecânico. São Paulo: Manole, 2002

2. American Gastroenterological Association (AGA). Thecnical review on the clinical use of esophageal manometry. Gastroenterology, 128:209-224, 2005.

3. Fernades FE et al. Efeito do treinamento muscular respiratório por meio do manovacuômetro e do Threshold Pep em pacientes hemiparéticos hospitalizados, in: Carmen Mueller-Karger, SaraWong Alexandre La Cruz (eds.). CLAIB 2007, IFMBE Prceedings, 2007.
4. Gomes J. et al. Esophageal Manometry. In: GI Motility Testing: A Laboratory and Office Handbook, 2:15-24, 2011.

5. Mittal RKetal. Human lower esophageal sphincter pressure response to increased intra-abdominal pressure. Am. J. Physiol. Gastrointest. Liver Physiol., 258:624-630, 1990.

6. Nicodème F, Lin Z, Pandolfino JE, Kahrilas PJ. Esophago-gastric junction pressure morphology: comparison between a station pullthrough and real-time 3D-HRM representation. Neurogastroenterol Motil., 25(9):e591-8, 2013.

7. Novais Luis. Avaliação funcional do esfíncter esofágico inferior por manometria esofágica. J Port Gastrenterol. [periódico na Internet], 19(2): 59-61, 2012.

8. Nobre e Souza MÂ, Lima MJ, Martins GB, Nobre RA, Souza MH, Oliveira RB, Santos AA. Inspiratory muscle training improves antireflux barrier in GERD patients. Am J Physiol Gastrointest Liver Physiol 305(11):G862-7, 2013

9. Nobre eSouza MÂ, Bezerra PC, Nobre RA, Holanda ES, Dos Santos AA Increased inspiratory esophagogastricjunction pressure in systemic sclerosis: An add-on to antireflux barrier. World J Gastroenterol, 21;21(7):2067-72, 2015.

10. Pires VA. Treinamento muscular inspiratório em pacientes sob desmame da ventilação mecância [Tese - Mestrado]. São Carlos (SP): Universidade Federal de São Carlos:1999. 